\title{
Late HIV infection modulates the expression and activity of Cathepsin B, and its inhibitors in macrophages: implications in neuropathogenesis
}

\author{
Eillen Rodriguez ${ }^{1 *}$, Marines Plaud ${ }^{1}$, Rafael Romeu², Richard Skolasky ${ }^{3}$, Loyda Melendez ${ }^{1}$ \\ From $16^{\text {th }}$ International Symposium on HIV and Emerging Infectious Diseases \\ Marseille, France. 24-26 March 2010
}

\section{Background}

To determine the mechanism by which HIV infection alters the expression and activity of CATB and its inhibitor, cystatin B (CSTB).

\section{Methods}

Peripheral blood derived macrophages (MDM) were infected with HIV $_{\mathrm{ADA}}$ at a MOI of 0.1 and cultured for up to 12 days. Intracellular and extracellular expression of CATB, CST B and CSTC in uninfected and HIVinfected cells were analyzed by Western blots and ELISA at 6, 9 and 12 days post infection (days p.i.). Activity of CAT B after HIV infection was determined by fluorescence and confocal microscopy.

\section{Results}

Expression of CATB protein and its intracellular inhibitor, CSTB, was increased in HIV infected cells after 12 days p.i. compared to uninfected controls $(\mathrm{p}=<0.05)$. However CSTC increase was not significant in HIV infected cells. CATB was secreted to similar ( $>400 \mathrm{ng} / \mathrm{ml}$ ) levels in both HIV-infected and uninfected cells at higher levels than those proved by others to promote cell damage (100 ng/ml or more). Importantly, secreted CATB from HIV-infected MDMs was significantly $(\mathrm{p}=0.008)$ more active than that secreted from control cells throughout the extent of the infection.

\section{Discussion}

HIV infection increases the levels of active CATB in supernatants 4 times higher than those previously reported by other groups to be toxic to neuronal cells.

\footnotetext{
* Correspondence: eillen.rodriguez@upr.edu

${ }^{1}$ University of Puerto Rico Medical Sciences Campus, San Juan, Puerto Rico
}

Although CSTB increased in HIV-infected cultures, no effective inhibition of CATB was seen at 12 days potinfection. Our results suggest that HIV infection is capable of altering the interactions between CATB and its inhibitors promoting, an increase in active CATB secretion, which may contribute to neuronal damage.

\section{Acknowledgements \\ Supported in part by R01MH083516, U54NS43011, GM061838, Biomedical Sciences Associate Deanship and Institutional funds.}

\section{Author details}

University of Puerto Rico Medical Sciences Campus, San Juan, Puerto Rico. ${ }^{2}$ University of Puerto Rico: Main Campus, San Juan, Puerto Rico. ${ }^{3}$ John Hopkins University, Baltimore, Maryland, USA.

Published: 11 May 2010

doi:10.1186/1742-4690-7-S1-P10

Cite this article as: Rodriguez et al:: Late HIV infection modulates the expression and activity of Cathepsin B, and its inhibitors in macrophages: implications in neuropathogenesis. Retrovirology 2010 7(Suppl 1):P10.

Submit your next manuscript to BioMed Central and take full advantage of:

- Convenient online submission

- Thorough peer review

- No space constraints or color figure charges

- Immediate publication on acceptance

- Inclusion in PubMed, CAS, Scopus and Google Scholar

- Research which is freely available for redistribution 